\title{
Types of agglomeration economies: effects on business innovation
}

\author{
Enrique Claver-Cortés ${ }^{1}$, Bartolome Marco-Lajara' ${ }^{1}$ Encarnacion Manresa-Marhuenda
}

ABSTRACT

KEY WORDS:

JEL Classification:

${ }^{1}$ Department of Management, University of Alicante, Spain

\begin{abstract}
A review of the literature does not provide conclusive results about the effects caused by firm agglomeration on innovation. In order to shed light on this issue, this paper draws a distinction among three kinds of agglomeration economies and empirically tests their respective impact on business innovation. The advantage that external knowledge generated through concentration can bring to each company depends on its absorptive capacity. Hence, it is posited that this dynamic capability acts as a mediator in the relationship between agglomeration and innovation. Using data from a survey conducted in 2013 by the Technological Innovation Panel (PITEC), an analysis of these ideas was performed using a sample of 2,906 high and medium-high technology companies. The results obtained indicate that several types of agglomeration economies exist and that the net effect each one of them has on innovation is different. More specifically, only urbanization economies favor innovation. Additionally, all of our findings reveal that firms increase their greater absorptive capacity in the context of agglomeration.
\end{abstract}

Innovation, Agglomeration, Externalities, Absorptive Capacity

O3

\section{Introduction}

Given that innovation -which generates growth, efficiency and profit in today's world- constitutes a key element in competitiveness, firms must innovate if they want to survive (Beugelsdijk, 2007). According to the Oslo Manual, innovation refers to the conception and implementation of significant changes in products, marketing, technical processes, and organizational processes for the purpose of improving firm performance (OECD/Eurostat, 2005).

Correspondence concerning this article should be addressed to: Bartolome Marco-Lajara, Department of Management, University of Alicante, P.O. Box 99, E-03080 Alicante, Spain. E-mail: bartolome.marco@ua.es
However, the complexity that characterizes the environment of many industries forces companies not only to cooperate but also to exploit external knowledge and combine it with internal sources of knowledge (Chesbrough, 2003).

Although access to external knowledge may prove difficult, the physical proximity of firms favors their mutual interactions as does the existence of a set of common standards and values that enable the exchange and transfer of (tacit) knowledge. The latter is linked to the agglomeration of firms and institutions in a geographical area, i.e., agglomeration economies (Marshall, 1920). In this sense, a line of research forecasts a positive effect of localization in agglomerations on firm innovation and performance. 
Regarding the impact of location on business innovation, the dynamic capabilities approach indicates that the effect varies across companies, depending on the individual capabilities of each company (Maskell \& Malmberg, 1999; Stuart \& Sorenson, 2003), especially that of one of the most often analyzed capabilities in recent years, namely, absorptive capacity (Giuliani \& Bell, 2005; Molina-Morales, García-Villaverde, \& Parra-Requena, 2014). Dynamic capabilities are defined as organizational skills that allow firms to integrate, reconfigure, renew, and create internal and external resources to develop and maintain competitive advantages as a response to the constant and increasing changes in the business environment (Teece, Pisano, \& Shuen, 1997; Winter, 2003). From this perspective, the aim of this paper is to analyze and provide empirical evidence of the role that absorptive capacity (AC) plays in the relationship between agglomeration and business innovation.

This dynamic capability was described by Cohen and Levinthal (1990) as representing "a firm's ability to value, assimilate, and apply new knowledge." In turn, Kim (1998) defines absorptive capacity as "the ability to learn and solve problems," whereas Zahra and George (2002) contend that it is "a set of organizational processes and routines whereby firms acquire, assimilate, transform, and exploit knowledge in order to produce a dynamic organizational capability." Other researchers, such as Lane, Koka and Pathak (2006, p. 856), have broadened the concept by defining it as "a firm's ability to utilize external knowledge through a sequential exploratory, transformative, and exploitative learning process." Thus, AC is envisaged as a source of competitive advantage that plays a central role in the development of competences, capabilities, and innovations and in the creation of knowledge (Cohen \& Levinthal, 1990), insofar as increased AC implies greater skill with respect to external knowledge achievement and implementation, thereby extending their possibilities compared to firms that, in the best of cases, can only exploit internal knowledge.

Seeking to achieve our aims, the literature review provided in Section 2 contributes to the task of hypothesis formulation, and Section 3 explains the methodology applied in the empirical research. After presenting the results of our study in Section 4, the conclusions drawn from our research are summarized in Section 5.

\section{Literature review}

\subsection{Effects of agglomeration economies on business innovation}

According to studies on agglomeration, the concentration of economic activity generates different types of externalities (Anselin, Varga, \& Acs, 1997; Audretsch, 2003). These external economies, also known as economies of agglomeration, assume that the profits of a firm located near other firms increase as the number of firms in the same location increases (Appold, 1995). However, recent studies find that agglomeration can also have negative effects on business profits because greater competition exists among companies to obtain necessary inputs, such as land, employees, etc. (Arikan \& Schilling, 2010; Flyer \& Shaver, 2003; Folta, Cooper, \& Baik, 2006; Glaesmeier, 1991; Pouder \& St. John, 1996; Prevezer, 1997).

The purpose of this paper is to clarify the ambiguity surrounding the relationship between agglomeration and innovation. We begin by distinguishing among the three types of agglomeration economies that may prove beneficial for innovation depending on the type of co-located firms, namely, urbanization economies, localization economies, and knowledge-intensive economies.

Urbanization economies (Jacobs, 1969) are those derived from the concentration of companies that develop various economic activities in a particular area or region. This plurality of technological and commercial realities carries multiple and varied types of knowledge that firms can share and combine, thus enhancing innovation (Frenken, van Oort, \& Verburg, 2007). It is in this context that inter-firm cooperation becomes feasible and allows for the generation of new knowledge, insofar as these firms are not rivals because they come from different industrial sectors. Moreover, creativity and innovation are likely to be favored through the combination of heterogeneous knowledge stemming from various industrial and commercial environments. As such a spatial concentration of activities without sectorial or industrial specialization is also characterized by a wider range of infrastructures, specialized services, and agents that act as middlemen and are responsible, to some extent, for the 
investment attraction effect. A first hypothesis is formulated based on these thoughts.

Hypothesis 1: Business innovation increases with urbanization economies.

Localization economies (Glaeser, Kallal, Scheinkman, \& Shleifer, 1992; Marshall, 1920) are those derived from the concentration of companies that develop the same economic activity in a specific area or region. This geographical concentration produces externalities that allow firms to learn from each other. In this case, apart from the transmission of knowledge and ideas across companies, the use of the same language, together with the existence of a common knowledge base, permits greater interaction among firms and generates greater possibilities for new knowledge creation. Thus, we present the following hypothesis:

Hypothesis 2a: Business innovation increases with localization economies.

Conversely, a higher concentration of potential competitors in the same place implies a greater relative shortage of resources, particularly that of valuable knowledge. In other words, although it is true that knowledge is not necessarily exhausted, it stops being valuable once it becomes indiscriminately accessible to any rival. That is why, within a context of physical proximity characterized by greater exposure to possible imitators, those firms that generate and take advantage of external knowledge must invest in the protection of that knowledge. This reallocation of resources meant for isolation and protection will most probably prove detrimental to investments in innovation.

Furthermore, in this regard, aside from the risk of being plundered by imitators, those firms that are best equipped in terms of knowledge will choose not to be located in places characterized by the concentration of competitors.

Taking into account both lines of reasoning allows us to conclude that being located in an environment with a higher concentration of firms belonging to the same industrial sector favors innovation up to a certain level of agglomeration after which saturation becomes excessive and the net effect on innovation then becomes negative (Marco-Lajara, Claver-Cortés,
Úbeda-García, \& Zaragoza-Sáez, 2016; Melo, Graham, \& Noland, 2009; Sorensen \& Sorenson, 2003). Consequently, we advance the following hypothesis:

Hypothesis 2b: An inverted U-shaped relationship exists between business innovation and localization economies.

Knowledge-intensive economies (Knoben, Raspe, Arikan, \& Oort, 2016) arise in locations next to firms and/or organizations that produce knowledge, in an environment where knowledge is valued, transferred, and generated. This knowledge-intensity is an essential feature of regions without industry specialization and where innovative and knowledge-oriented agents are located. Thus, we formulate Hypothesis 3.

Hypothesis 3: Business innovation increases with knowledge-intensive economies.

\subsection{The mediation effect of absorptive capacity}

Even though a large number of firms may actually be exposed to identical environmental conditions, not all of them are able to convert outside knowledge into results with the same levels of success because they differ in their abilities to use these sources of knowledge (Caloghirou, Kastelli, \& Tsakanikas, 2004; Rothaermel \& Hess, 2007).

In fact, the existence of more external sources of potentially useful knowledge increases the possible combinations of knowledge and, therefore, the complexity of its management. As a result, the inability of firms to manage and exploit that knowledge can limit their possibilities for innovation (Henderson \& Clark, 1990; Laursen \& Salter, 2006), which is why it is necessary to highlight the role of AC (Cohen \& Levinthal, 1990). This capability, as related to the firm's ability to learn, constitutes a multidimensional construct that makes knowledge acquisition, assimilation, transformation, and exploitation possible.

Several authors suggest breaking AC down into two dimensions (Jansen, Van Den Bosch, \& Volberda, 2005) that are related to one another through mutual influences (Katila \& Ahuja, 2002), namely, potential absorptive capacity (PAC) and realized absorptive capacity (RAC). PAC allows a firm to be receptive to knowledge coming from the outside and is influenced 
by, among other things, the prior knowledge owned by the firm and its participation in alliances, whereas RAC represents the ability to generate and apply new knowledge by taking the existing knowledge as a reference and investing in regenerating and updating that knowledge. Furthermore, bearing in mind that knowledge has a cumulative nature, RAC may depend on the level of education, experience, and training of employees. In this respect, the greater this training is, the greater is the ability to implement and profit from the knowledge that has been absorbed.

In relation to the link between $\mathrm{AC}$ and innovation, it has been found that AC positively impacts the chances for technological innovation (Cepeda-Carrión, Cegarra-Navarro, \& Jiménez-Jiménez, 2012), process and organizational innovation (Murovec \& Prodan, 2009), product innovation (George, Zahra, Wheatley, \& Khan, 2001), patenting (Sørensen \& Stuart, 2000), etc. Thus, the following hypothesis is posed:

Hypothesis 4: AC has a positive effect on business innovation.

The agglomeration of firms encourages their participation in networks and alliances. Such collaboration occurs in various ways. For example, collaboration can be established between non-rival firms seeking knowledge complementarity, between rival companies' intent on creating mutually valuable knowledge, and between firms and other organizations interested in knowledge generation.

In any case, this interaction appears to be a determining factor of AC (Caloghirou et al., 2004) as both the learning and the accumulation of the knowledge that lies at the base of AC are gradual processes of an interactive and social nature. Accordingly, AC depends on the external context where it develops.

It is also important to emphasize that apart from fostering the generation of a skilled labor market, geographic concentration also contributes to creating knowledge and skills for the workers of agglomerated firms, as this labor market ensures a certain base of knowledge and skills that positively impacts organizational AC when employed (Tallman, Jenkins, Henry, \& Pinch, 2004).

Finally, the literature mentions other drivers, such as the level of previous internal knowledge (number of patents), employee skills, periodical investments in innovation ( $R \& D$, training), etc., and highlights the importance that corresponds to the allocation of resources. This allocation depends on the expectations of potentially profitable external knowledge. Moreover, those expectations are greater in those environments where access to external knowledge and learning are more likely and more profitable from the perspective of their exploitation (Kaiser, 2002; Veugelers, 1997). Based on these ideas, we formulate the following hypothesis:

Hypothesis 5: Agglomeration economies have a positive effect on $A C$.

Together, Hypotheses 4 and 5 lead to another hypothesis that predicts a mediating effect of AC on the link between agglomeration and innovation:

Hypothesis 6: AC mediates the relationship between agglomeration and business innovation.

\section{Empirical research}

\subsection{Methodology}

Although the present study tests the hypotheses using a multiple linear regression, a variety of models are estimated because not all hypotheses can be tested in the same way. H1, H2a, and $\mathrm{H} 3$ predict a direct effect of the independent variable (agglomeration) on the dependent variable (innovation); H4, H5, and H6 forecast a mediating effect; and $\mathrm{H} 2 \mathrm{~b}$ predicts a nonlinear effect.

Furthermore, with respect to $\mathrm{H} 1, \mathrm{H} 2 \mathrm{a}$, and $\mathrm{H} 3$, the model exhibits a general formulation such that $\mathrm{Y}=\beta_{10}+\beta_{11}^{*} \mathrm{X}+\beta_{12}^{*} \mathrm{C}$, where $\mathrm{Y}$ is the dependent variable, $\mathrm{X}$ is the independent variable, and $\mathrm{C}$ is the control variable.

According to Judd and Kenny (1981) and Baron and Kenny (1986), the analysis of the mediating effect requires the formulation of three equations. In the first equation, the dependent variable is estimated using independent and control variables, and the equation is the same as that of the direct effect. In the second equation, the mediator variable is estimated using independent and control variables. Regarding the third, the dependent variable 
is simultaneously estimated using the independent, mediator, and control variables:

$\mathrm{Y}=\beta_{10}+\beta_{11}^{*} \mathrm{X}+\beta_{12}^{*} \mathrm{C}+\varepsilon_{1}$

$\mathrm{Me}=\alpha_{20}+\alpha_{21}{ }^{*} \mathrm{X}+\alpha_{22}{ }^{*} \mathrm{C}+\varepsilon_{2}$

$\mathrm{Y}=\beta_{30}+\beta_{31}{ }^{*} \mathrm{X}+\beta_{32}{ }^{*} \mathrm{Me}+\beta_{33}{ }^{*} \mathrm{C}+\varepsilon_{3}$

Several requirements must be fulfilled to verify the mediating effect, specifically, a statistically significant and non-zero independent variable coefficient in all three equations; a statistically significant and nonzero mediator variable coefficient in the last equation; the absolute value corresponding to the residual effect of the independent variable on the dependent variable, after granting the mediating indirect effect is less than the absolute value of the total effect. In other words, $\beta_{11} \neq 0, \alpha_{21} \neq 0, \beta_{32} \neq 0$ and $/ \beta_{31} /</ \beta_{11} /$-all of these coefficients must be statistically significant.

Considering all of the study variables, the verification model is expressed as follows:

INNOVATION $=\beta_{10}+\beta_{11} *$ AGGLOMERATION + $+\beta_{12}{ }^{*}$ CONTROL VAR. $+\varepsilon_{1}$

$\mathrm{AC}=\alpha_{20}+\alpha_{21}$ AGGLOMERATION + $+\alpha_{22} *$ CONTROL VAR. $+\varepsilon_{2}$

INNOVATION $=\beta_{30}+\beta_{31} *$ AGGLOMERATION + $+\beta_{32}{ }^{*} \mathrm{AC}+\beta_{33}{ }^{*} \mathrm{CONTROL}$ VAR. $+\varepsilon_{3}$

where $\beta_{11} \neq 0, \alpha_{21} \neq 0, \beta_{31} \neq 0$ and $/ \beta_{31} /</ \beta_{11} /$. All of these coefficients must be statistically significant.

Our final task is to verify $\mathrm{H} 2 \mathrm{~b}$ using a non-linear or quadratic equation. The estimating model adopts the following formulation:

$\mathrm{Y}=\beta_{40}+\beta_{41}^{*} \mathrm{X}+\beta_{42}^{*} \mathrm{X}^{2}+\beta_{43}^{*} \mathrm{C}+\varepsilon_{4}$

INNOVATION $=\beta_{40}+\beta_{41}{ }^{*}$ AGGLOMERATION + $+\beta_{42}{ }^{*}$ AGGLOMERATION ${ }^{2}+\beta_{43}{ }^{*}$ CONTROL VAR $+\varepsilon_{4}$

The verification of $\mathrm{H} 2 \mathrm{~b}$ requires that $\beta_{42}<0$ and be statistically significant.

The IBM Statistical Package for the Social Sciences (SPSS) version 23 was used to conduct the calculations.

\subsection{Measurement of variables}

The work performed to measure all the variables specified in the equations is supported by the PITEC (Panel de Innovación Tecnológica) database, elaborated using a questionnaire about innovation in business.

\subsubsection{Dependent variable}

Two approaches were considered when estimating INNOVATION. One of the commonly used measures refers to the number of patents for which a company has filed an application (Dutta \& Weiss, 1997; Henderson \& Cockburn, 1994; Squicciarini, 2008; 2009; VásquezUrriago, Barge-Gil, Modrego-Rico, \& Paraskevopoulou, 2014). Therefore, our proposal includes the PATNUM variable, which measures the number of patent applications filed between 2011 and 2013. However, one of the drawbacks to this this index is that it fails to consider that not all firms register their innovations with patents.

Furthermore, the term innovation can be measured in a broader sense, which led us to check whether the firm had innovated or modernized products, technical processes, organizational practices, or commercial strategies between 2011 and 2013. Accordingly, the values of thirteen dichotomous variables from the PITEC database, which evaluates the different types of innovations in each firm, allowed us to calculate the variable INNOVA, which aggregates the data for each firm (PITEC, 2013). The value of this variable ranges between 0 , indicating the firm has not innovated, and 13, indicating it has innovated in every business area (Montoro-Sánchez, Mora-Valentín, \& Ortiz-de-Urbina-Criado, 2012).

A principal components factor analysis was applied with both approaches, which explains $65.55 \%$ of variance.

\subsubsection{Independent variables}

URB.AGGL. represents urbanization economies generated in cities and urban areas. The problem lies in the fact that the PITEC database does not provide any information about the city where the firm's $R \& D$ area is located. Hence, we use a proxy variable to indicate whether the firm is located in a scientific and technologic park (STP). This dichotomous variable takes either a 1 if located in an STP or a 0 value otherwise.

STPs are comprised of an agglomeration of firms from several and different industries and other orga- 
nizations. Cooperation between businesses and organizations is fostered in such locations, and a physical as well as social infrastructure exists that stimulates the creation, access, and acquisition of external knowledge. Accordingly, innovation is encouraged in such locations (Squicciarini, 2008; 2009; Siegel, Westhead, \& Wright, 2003).

LOC.AGGL. Localization economies result from the geographic concentration of similar firms in a given area, an autonomous region in our case. The fact that many firms are located in several regions caused us to adopt a criterion when determining the autonomous region associated with each company, more precisely, the place where each firm develops its internal R\&D. In this sense, it was decided that this place corresponds to the physical location of R\&D workers. The data reveal that $59.73 \%(1,736)$ of the firms in our sample have staff who develop their professional activity in R\&D on a full-time basis and that $92.74 \%(1,610)$ of those firms concentrate their $\mathrm{R} \& \mathrm{D}$ personnel in a single autonomous region, whereas the remaining 126 own assets in several regions.

Bearing all this information in mind, the proportion of high and medium-high technology firms to the total number of firms in each autonomous region enabled us to estimate the LOC.AGGL variable (the data correspond to 2013).

KNOW.AGGL. Knowledge-intensive economies underscore the importance of orientation to innovation, as exhibited by an area or region, on performance with respect to the degree of innovation implemented by the firms located in the specific area or region. Autonomous regions were also chosen as reference geographical areas. Using data provided by the INE [Spanish National Statistics Institute], the following variables that indicate the propensity of an autonomous region to innovation were considered: innovation intensity corresponding to the total number of companies (= spending in innovative activities x 100/sales volume); percentage of sales in new or improved products; percentage of employees with higher education; and percentage of innovative firms. A principal components factor analysis explaining $81.61 \%$ of the variance for the KNOW.AGGL variable was applied with those four indices.

ABSORPTIVE CAPACITY (AC). AC is a function of the knowledge to which firms can gain access com- bined with the means used to exploit that knowledge. Therefore, this multidimensional construct results from combining potential absorptive capacity (PAC) and realized absorptive capacity (RAC).

With respect to PAC, the variable EXTSOURC scores the number of external sources of knowledge (machine suppliers, clients/customers, competitors, consultants, private laboratories, universities, public research bodies, technology centers, conferences, fairs or exhibitions, scientific journals, industrial and professional associations) that can be assessed as being of high importance by firms. The value of EXTSOURC ranges from 0 to 9 . The opportunity for each firm to access external knowledge through successful alliances, for which the variable SUCCALL was estimated, was also considered. SUCCALL receives a score of 1 if the firm has engaged in developing or innovating products, technological processes, organizational practices, or commercial strategies with other firms or institutions. A principal components factor analysis performed with these two variables enabled us to extract one factor that explains $60.46 \%$ of the PAC variance.

As for RAC, the literature often uses measures related to R\&D expenditure. Therefore, our study focused on the percentage of internal expenditure R\&D over the total expenditure in R\&D (INTR\&D). RAC not only depends on the implementation of such investments, but its use as an indicator could actually penalize the importance of smaller-sized organizations that are unable to carry out R\&D activities on a regular basis. Perhaps for this reason, several studies ultimately stressed the importance of human resources when identifying and assessing this capability (Mangematin \& Nesta, 1999). In keeping with the previous line of reasoning, the following indicators were considered: the relative importance of research staff with respect to the entire staff -denoted by the variable RESTAFFand whether the RAC has a twofold dimension depending on the source of information, i.e., scientific or market-related, on which it is supported (Caloghirou et al., 2004; Murovec \& Prodan, 2009). Hence our decision to take two variables into account, namely, R\&DSTAFF (percentage of R\&D staff employed in internal R\&D) and HIGHEDU (percentage of employees who have completed higher education). A principal components factor analysis performed with the aforementioned four variables allowed us to extract a 
Table 1. Sample firm distribution by activity sector

\begin{tabular}{|c|c|c|}
\hline CNAE 2009 & HIGH \& MEDIUM-HIGH TECHNOLOGY SECTOR & $\mathrm{N}^{*}$ \\
\hline & High-Tech Manufacturing Sector & 376 \\
\hline 21 & Pharmaceutical & 128 \\
\hline 26 & Computer, Electronic and Optical & 230 \\
\hline \multirow[t]{2}{*}{30.3} & Aircraft and Spacecraft and Related Machinery & 18 \\
\hline & Medium-High Technology Manufacturing Sector & 1,555 \\
\hline 20 & Chemicals and Chemical Products & 488 \\
\hline $27-28-29$ & $\begin{array}{l}\text { Electrical Equipment; General-Purpose Machinery; Motor Vehicles, Trailers and } \\
\text { Semi-Trailers }\end{array}$ & 1,020 \\
\hline \multirow[t]{2}{*}{$30-30.1$} & Manufacture of other transport equipment; Building of ships and boats & 47 \\
\hline & High-Tech Service Sector & 975 \\
\hline $59-58-60-61-62-63$ & $\begin{array}{l}\text { Motion Picture, Video and Television Program Production, Sound Recording } \\
\text { and Music Publishing; Programming and Broadcasting; Telecommunications; } \\
\text { Computer Programming, Consultancy and Related; Information Service }\end{array}$ & 777 \\
\hline \multirow[t]{2}{*}{72} & Scientific Research and Development & 198 \\
\hline & TOTAL & 2,906 \\
\hline
\end{tabular}

* Number of firms

Source: PITEC (2013)

factor that explains $77.81 \%$ of the RAC variance. $\mathrm{Fi}$ nally, the measure that represents the $\mathrm{AC}$ was obtained from a factorial analysis of these two factors (PAC and RAC), which explains $73.35 \%$ of the variance.

\subsubsection{Control variables}

AGE. The number of years during which a firm has been operating since its foundation can influence innovation both positively and negatively. Indeed, greater experience is likely to permit a higher accumulation of knowledge, but it may also become an inertiagenerating source that hinders both adaptation and the introduction of novelties in products and processes.

SIZE. Size is significantly correlated with innovation, even though no consensus exists as to whether this relationship is positive or negative. On the one hand, larger firms can be more innovative due to their greater financial holdings, but on the other hand, the higher flexibility and the better communication level actually allows smaller-sized firms to be the most innovative (Damanpour \& Gopalakrishnan, 1998). A dichotomous variable, SIZE200, which shows whether the firm is defined as large because it has over 200 employees or is not large, was added to our model to assess this effect.

GEOGRAPHIC SCOPE. The greater or lesser predisposition to innovate may additionally be determined by sales expectations, which in turn are going to depend on the breadth of the geographical markets that constitute the product or service target (Löfsten \& Lindelöf, 2003). Thus, sales dispersion will also most likely encourage innovation because of the need to adapt products to the local demand and to the regulations of foreign markets (Vernon, 1966). Based on the information presented herein and following other works such as that authored by Urgal, Quintás and Arévalo-Tomé (2011), the categorical variable GEOGSCOPE was included with three pos- 
sible situations or values, namely, the local, national, and international markets.

BUSINESS GROUP. Every firm's need to acquire external knowledge, and ultimately to innovate, depends on its affiliation to a business group (Barge-Gil, Vásquez, \& Rico, 2011). This was measured by means of a dummy variable that takes the value 1 if it belongs to a business group and 0 otherwise.

\subsection{Population and sample}

The study object of this paper is formed by those firms that have innovated, that is, firms that have engaged in any activity oriented to achieve new or significantly improved products or processes. Previous studies suggest that the dynamism or the technological turbulence typical of each industry is a variable that can largely influence not only greater or lesser proneness to innovation but also other variables relevant for this study, such as AC (Martínez-Senra, Quintás, Sartal, \& Vázquez, 2013). This led us to complete our analysis with the innovative firms belonging to sectors that exhibit similar degrees of technological turbulence, more precisely, medium-technology and high-technology sectors. Following the classification adopted by INE, medium-technology and high-technology sectors may include both manufacture and service sectors. INE's estimates for 2013 placed the number of firms belonging to these two sectors at 4,823 in Spain.

With regard to the sample, the PITEC database served as the basis for our work. The survey conducted by PITEC in 2013 included the responses of 10,074 firms, 2,906 of which (just above 28.84\%) belonged to the medium-high technology and high technology sectors. Table 1 displays the distribution of firms by activity sectors.

\section{Results}

The following tables summarize the results of all the models estimated. ${ }^{1}$ As presented in Table 2, H1, H4 (this effect is included in every table), and $\mathrm{H} 5$ were verified when considering the urbanization economies generated in a STP. Moreover, confirmation was equally obtained for $\mathrm{H} 6$, according to which AC mediates the influence of agglomeration on business innovation.

Instead, Tables 3 and 4 test the effect of localization economies on business innovation $(\mathrm{H} 2 \mathrm{a}$ and
$\mathrm{H} 2 \mathrm{~b})$. The absence of a direct and significant effect becomes evident, which means that neither $\mathrm{H} 2 \mathrm{a}$ nor $\mathrm{H} 2 \mathrm{~b}$ are verified. It can, however, be proved that these economies directly and significantly impact the AC of firms (H5). An additional regression was performed in which the relationship between AC and the localization economies was non-linear. The results of that regression indicate that $\mathrm{AC}$ increases up to a certain level of agglomeration at which point it then begins to decrease. This is the effect as predicted by H2b for business innovation.

Finally, knowledge-intensive economies exhibit the same patterns as do the other types of economies (Table 5). Moreover, they do not have a direct and significant effect on innovation, which prevents us from validating $\mathrm{H} 3$ and $\mathrm{H} 6$, but they do cause such an effect on $\mathrm{AC}$ (H5).

With regard to control variables, despite the fact that none of the control variables has a significant effect on absolute value as none of the estimated coefficients exceeds one, all but AGE cause a positive effect and are statistically significant in every estimated equation.

\section{Discussion, conclusions, and future lines of research}

Part of the literature dedicated to studying the effect of location on business profits has traditionally identified location and agglomeration as determining factors of business innovation. However, this literature does not provide conclusive results regarding the extent to which firm agglomeration influences innovation. Seeking to provide insight on this issue, the present paper distinguishes three types of agglomeration economies, namely, urbanization economies, localization economies, and knowledge-intensive economies, and empirically tests the effect that each of these economies has on business innovation.

Each one of the three externalities has some bearing on innovation for reasons associated with knowledge externalities, that is, the external knowledge of a collective nature that firms access, acquire, and use to improve their profits. Nevertheless, the exploitation of this location effect is far from symmetrical or similar. Considering the dynamic capabilities approach as a reference, the literature review has allowed us to highlight that absorptive capacity played a key role in the relationship between location and 
Table 2. Testing the Mediating and Direct Effects of URG.AGGL and AC on INNOVATION

\begin{tabular}{|c|c|c|c|c|c|}
\hline & \multirow[b]{2}{*}{ DEPENDENT VARIABLE } & \multirow[b]{2}{*}{ INNOVATION } & \multirow{2}{*}{$\begin{array}{c}\text { DIRECT EFFECT } \\
\text { INNOVATION }\end{array}$} & \multicolumn{2}{|c|}{ MEDIATING EFFECT } \\
\hline & & & & $A C$ & INNOVATION \\
\hline \multirow{8}{*}{ 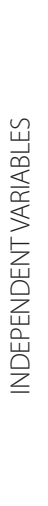 } & URG.AGGL & & $0.513^{* * *}$ & $0.708^{* * *}$ & $0.243^{* * *}$ \\
\hline & $A C$ & & & & $0.381^{* * *}$ \\
\hline & AGE & 0.001 & $0.002^{* *}$ & 0.002 & $0.002^{*}$ \\
\hline & GROUP & $0.102^{* * *}$ & $0.107^{* * *}$ & $0.087^{* *}$ & $0.074^{* *}$ \\
\hline & SIZE200 & $0.539^{* * *}$ & $0.523^{* * *}$ & $0.124^{* *}$ & $0.475^{* * *}$ \\
\hline & GEOGSCOPE & $0.257^{* * *}$ & $0.250^{* * *}$ & $0.328^{* * *}$ & $0.125^{* * *}$ \\
\hline & Constant & $-0.866^{* * *}$ & $-0.921^{* * *}$ & $-1.055^{* * *}$ & $-0.519 * * *$ \\
\hline & $\mathrm{R}^{2}$ & 0.079 & 0.098 & 0.078 & 0.232 \\
\hline
\end{tabular}

Table 3. Testing the Mediating and Direct Effects of LOC.AGGL and AC on INNOVATION

\begin{tabular}{|c|c|c|c|c|c|}
\hline & & & \\
\hline & \multirow[b]{2}{*}{ DEPENDENT VARIABLE } & \multirow[b]{2}{*}{ INNOVATION } & \multirow{2}{*}{$\begin{array}{c}\text { DIRECT EFFECT } \\
\text { INNOVATION }\end{array}$} & \multicolumn{2}{|c|}{ MEDIATING EFFECT } \\
\hline & & & & $A C$ & INNOVATION \\
\hline \multirow{8}{*}{ 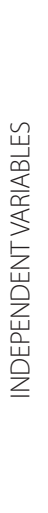 } & LOC.AGGL & & -0.220 & $0.323^{* *}$ & $-0.326^{*}$ \\
\hline & $A C$ & & & & $0.327^{* * *}$ \\
\hline & AGE & 0.001 & 0.001 & $-0.002^{* *}$ & 0.002 \\
\hline & GROUP & $0.102^{* * *}$ & 0.068 & -0.021 & $0.075^{*}$ \\
\hline & SIZE200 & $0.539^{* * *}$ & $0.461^{* * *}$ & 0.025 & $0.453^{* * *}$ \\
\hline & GEOGSCOPE & $0.257^{* * *}$ & $0.175^{* * *}$ & $0.067^{*}$ & $0.153^{* * *}$ \\
\hline & Constant & $-0.866^{* * *}$ & $-0.341^{* *}$ & $0.462^{* * *}$ & $-0.492^{* * *}$ \\
\hline & $\mathrm{R}^{2}$ & 0.079 & 0.074 & 0.007 & 0.151 \\
\hline & ${ }^{*} p<0.1$; $^{*}$ & 01 & & & \\
\hline
\end{tabular}


Table 4. Testing the Mediating and Direct Effects of LOC.AGGL ${ }^{2}$ and $A C$ on INNOVATION

\begin{tabular}{|c|c|c|c|c|c|}
\hline & \multirow[b]{2}{*}{ DEPENDENT VARIABLE } & \multirow[b]{2}{*}{ INNOVATION } & \multirow{2}{*}{$\begin{array}{c}\text { DIRECT EFFECT } \\
\text { INNOVATION }\end{array}$} & \multicolumn{2}{|c|}{ MEDIATING EFFECT } \\
\hline & & & & $\mathrm{AC}$ & INNOVATION \\
\hline \multirow{8}{*}{ 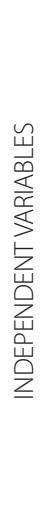 } & LOC.AGGL ${ }^{2}$ & & -0.385 & $0.458^{* *}$ & $-0.535^{*}$ \\
\hline & $A C$ & & & & $0.327^{* * *}$ \\
\hline & AGE & 0.001 & 0.001 & $-0.002^{* *}$ & 0.002 \\
\hline & GROUP & $0.102^{* * *}$ & 0.068 & -0.019 & $0.074^{*}$ \\
\hline & SIZE200 & $0.539^{* * *}$ & $0.461^{* * *}$ & 0.024 & $0.453^{* * *}$ \\
\hline & GEOGSCOPE & $0.257^{* * *}$ & $0.174^{* * *}$ & $0.067^{*}$ & $0.152^{* * *}$ \\
\hline & Constant & $-0.866^{* * *}$ & $-0.341^{* *}$ & $0.504^{* * *}$ & $-0.527^{* * *}$ \\
\hline & $\mathrm{R}^{2}$ & 0.079 & 0.074 & 0.006 & 0.150 \\
\hline & ${ }^{*} p<0.1 ;{ }^{* *} p<0.05 ; *$ & 1. & & & \\
\hline
\end{tabular}

Table 5. Testing the Mediating and Direct Effects of KNOW.AGGL and AC on INNOVATION

\begin{tabular}{|c|c|c|c|c|c|}
\hline & & & \\
\hline & \multirow[b]{2}{*}{ DEPENDENTVARIABLE } & \multirow[b]{2}{*}{ INNOVATION } & \multirow{2}{*}{$\begin{array}{c}\text { DIRECT EFFECT } \\
\text { INNOVATION }\end{array}$} & \multicolumn{2}{|c|}{ MEDIATING EFFECT } \\
\hline & & & & $A C$ & INNOVATION \\
\hline \multirow{8}{*}{ 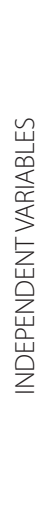 } & KNOW.AGGL & & -0.029 & $0.032^{*}$ & $-0.039^{* *}$ \\
\hline & $A C$ & & & & $0.327^{* * *}$ \\
\hline & AGE & 0.001 & 0.001 & $-0.002^{* *}$ & 0.002 \\
\hline & GROUP & $0.102^{* * *}$ & 0.069 & -0.020 & $0.076^{*}$ \\
\hline & SIZE200 & $0.539^{* * *}$ & $0.462^{* * *}$ & 0.023 & $0.454^{* * *}$ \\
\hline & GEOGSCOPE & $0.257^{* * *}$ & $0.175^{* * *}$ & $0.065^{*}$ & $0.154^{* * *}$ \\
\hline & Constant & $-0.866^{* * *}$ & $-0.392^{* * *}$ & $0.540^{* * *}$ & $-0.568^{* * *}$ \\
\hline & $\mathrm{R}^{2}$ & 0.079 & 0.074 & 0.006 & 0.151 \\
\hline
\end{tabular}

${ }^{*} p<0.1 ;{ }^{* *} p<0.05 ; * * * p<0.01$. 

In addition to the possible contributions made with this study, our work has a number of limitations. The first problem which deserves to be mentioned has to do with the causality involved in the relationship between some variables because that causality was imposed by the researchers. This led us to wonder if the positive relationship between AC and agglomeration economies occurs because the former comes as a consequence of the latter or if it is the other way round. In other words, if it is the agglomeration that favors a greater development of AC or, alternatively, if it is the higher level of development achieved in AC that determines the location in agglomeration areas for the purpose of gaining access to knowledge spillovers. The implementation of other more robust analysis techniques in the future might help to clarify this aspect.

As for the empirical results obtained, potential reasonable improvements can equally be suggested by using primary data specifically built for the interests of this research, together with other indicators to represent variables, constructs, etc. Furthermore, it should not be forgotten that each agglomeration (either in a country or in an autonomous region, an industrial district, or a STP) is different, insofar as the socio-economic conditions, the stage of the life cycle, the degree of agglomeration, or the diversity of firms, managers -amongst other things- vary, which has different implications for the firms located therein. Consequently, including the "individuality" of each agglomeration could prove interesting for a future line of research in which the characteristics of the agglomerations that determine whether firms are more profitable due to their location would be more easily identified.

\section{References}

Alcácer, J., \& Chung, W. (2014). Location strategies and knowledge spillovers. Management Science, 53(5), 760-776.

Anselin, L., Varga, A. \& Acs, Z. J. (1997). Local geographic spillovers between university research and high technology innovations. Journal of Urban Economics, 42(3), 422-448.

Appold, S. J. (1995). Agglomeration, interorganizational networks, and competitive performance in the US metalworking sector. Economic Geography, 71(1), 27-54.
Arikan, A. T., \& Schilling, M. A. (2010). Structure and governance in industrial districts: Implications for competitive advantage. Journal of Management Studies, 48(4), 772-803.

Audretsch, D. B. (2003). Innovation and spatial externalities. International Regional Science Review, 26(2), 167-174.

Barge-Gil, A., Vásquez-Urriago, A. \& Modrego-Rico, A., (2011). El impacto de los parques científicos y tecnológicos españoles sobre la innovación empresarial según distintos tipos de empresas. La innovación como factor de competitividad de la empresa española [The impact of the Spanish science and technology parks on business innovation according to different types of firms. Innovation as a factor in the competitiveness of the Spanish firm]. ICE: Revista de economía, 860, 73-88.

Baron, R. M., \& Kenny, D. A. (1986). The moderatormediator variable distinction in social psychological research: Conceptual, strategic and statistical considerations. Journal of Personality and Social Psychology, 51(6), 1173-1182.

Beugelsdijk, S. (2007). The regional environment and a firm's innovative performance: A plea for a multilevel interactionist approach. Economic Geography, 83(2), 181-199.

Boschma, R. A. \& Ter Wal, A. L. J. (2007). Knowledge networks and innovative performance in an industrial district: The case of a footwear district in the south of Italy. Industry and Innovation, 14(2), 177-199.

Breschi, S., \& Lissoni, F. (2001). Knowledge spillovers and local innovation systems: a critical survey. Industrial and Corporate Change, 10(4), 975-1005.

Caloghirou, Y., Kastelli, I., \& Tsakanikas, A. (2004). Internal capabilities and external knowledge sources: complements or substitutes for innovative performance? Technovation, 24(1), 29-39.

Cepeda-Carrión, G., Cegarra-Navarro, J. G., \& Jiménez-Jiménez, D. (2012). The effects of absorptive capacity on innovativeness: context and information systems capability as catalysts. British Journal of Management, 23(1), 110-129.

Chesbrough, H. W. (2003). The logic of open innovation: managing intellectual property. California Management Review, 45(3), 33-58. 
Cohen, W. M., \& Levinthal, D. A. (1990). Absorptive capacity: a new perspective on learning and innovation. Administrative Science Quarterly, 35(1), 128-152.

Colombo, M. G., \& Delmastro, M. (2002). How effective are technology incubators? evidence from Italy. Research Policy, 31(7), 1103-1122.

Damanpour, F., \& Gopalakrishnan, S. (1998). Theories of organizational structure and innovation adoption: the role of environmental change. Journal of Engineering and Technology Management, 15(1), 1-24.

Díez-Vial, I., \& Fernández-Olmos, M. (2015). Knowledge spillovers in science and technology parks: how can firms benefit most? The Journal of Technology Transfer, 40(1), 70-84.

Dutta, S., \& Weiss A. M. (1997). The relationship between a firm's level of technological innovativeness and its pattern of partnership agreements. Management Science, 43(3), 343-356.

Felsenstein, D. (1994). University-related science parks - 'seedbeds' or 'enclaves' of innovation? Technovation, 14(2), 93-110.

Ferguson, R., \& Olofsson, C. (2004). Science parks and the development of NTBFs-location, survival and growth. The Journal of Technology Transfer, 29(1), 5-17.

Flyer, F., \& Shaver, J. M. (2003). Location choices under agglomeration externalities and strategic interaction. In J. A. C. Baum, O. Sorenson (Eds.), Advances in Strategic Management: Geography and Strategy (Vol. 20, pp. 193-214). Amsterdam: Elsevier JAI.

Folta, T. B., Cooper, A. C., \& Baik, Y. (2006). Geographic cluster size and firm performance. Journal of Business Venturing, 21(2), 217-242.

Frenken, K., van Oort, F., \& Verburg, T. (2007). Relate variety, unrelated variety and regional economic growth. Regional Studies, 41(5), 685-697.

George, G., Zahra, S. A., Wheatley, K., \& Khan, R. (2001), The effects of alliance portfolio characteristics and absorptive capacity on performance: a study of biotechnology firms. Journal of High Technology Management Research, 12(2), 205-227.

Giuliani, E., \& Bell, M. (2005). The micro-determinants of meso-level learning and innovation: evidence from a Chilean wine cluster. Research Policy, 34(1), 47-68.
Glaeser, E. L., Kallal, H. D., Scheinkman, J. A., \& Shleifer A. (1992). Growth in Cities. The Journal of Political Economy, 100(6), 1126-1152.

Glasmeier, A. K. (1991). Technological discontinuities and flexible production networks: the case of Switzerland and the world watch industry. Research Policy, 20(5), 469-485.

Henderson, R. M. \& Clark, K. B. (1990). Architectural innovation: the reconfiguration of existing product technologies and the failure of established firms. Administrative Science Quarterly, 35(1), 9-30.

Henderson, R., \& Cockburn, I. (1994). Measuring competence? Exploring firm effects in pharmaceutical research. Strategic Management Journal, 15, 63-84.

Huang, K. F., Yu, C. M., \& Seetoo, D. H. (2012). Firm innovation in policy-driven parks and spontaneous clusters: the smaller firm the better? The Journal of Technology Transfer, 37(5), 715-731.

Jacobs, J. (1969). The Economy of Cities. New York, NY: Random House.

Jansen, J. J. P., Van Den Bosch, F. A. J., \& Volberda, H. W. (2005). Managing potential and realized absorptive capacity: how do organizational antecedents matter? Academy Management Journal, 48(6), 999-1015.

Jiménez-Moreno, J. J, Martínez-Cañas, R., Ruiz-Palomino, P., \& Sáez-Martínez, F. J. (2013). The role of science and technology parks in the generation of firm level social capital through university-firm relations: an empirical study in Spain. In J. J. M. Ferreira, M. Raposo, R. Rutten, \& A. Varga (Eds.), Cooperation, clusters, and knowledge transfer (pp. 19-34). Berlin: Springer.

Judd, C. M., \& Kenny, D. A. (1981). Process analysis: Estimating mediation in treatment evaluation. Evaluation Review, 5, 602-619.

Kaiser, U. (2002). An empirical test of models explaining research expenditures and research cooperation: evidence for the German service sector. International Journal of Industrial Organization, 20(6), 747-774.

Katila, R., \& Ahuja, G. (2002). Something old, something new: A longitudinal study of search behavior and new product introduction. Academy of Management Journal, 45(6), 1183-1194. 
Kim, L. (1998). Crisis construction and organizational learning: Capability building in catching up at Hyundai Motor. Organization Science, 9(4), 506-521.

Knoben, J., Raspe, O., Arikan, A. \& Oort, F. (2016). Agglomeration and firm performance: One firm's medicine is another firm's poison. Environment and Planning, 48(1), 132-153.

Lane, P., Koka, B., \& Pathak, S. (2006). The reification of absorptive capacity: a critical review and rejuvenation of the construct. The Academy Management Review, 31(4), 833-863.

Laursen, K., \& Salter, A. (2006). Open for innovation: The role of openness in explaining innovation performance among U.K. manufacturing firms. Strategic Management Journal, 27(2), 131-150.

Löfsten, H., \& Lindelöf, P. (2001). Science parks in Sweden - industrial renewal and development? R\&D Management, 31(3), 309-322.

Löfsten, H., \& Lindelöf, P. (2003). Determinants for an entrepreneurial milieu: Science parks and business policy in growing firms. Technovation, 23(1), 51-64.

Mangematin, V., \& Nesta, L. (1999). What kind of knowledge can a firm absorb? International Journal of Technology Management, 18(3-4), 149-172.

Marco-Lajara, B., Claver-Cortés, E., Úbeda-García, M., \& Zaragoza-Sáez, P. C. (2016). Hotel Performance and Agglomeration of Tourist Districts. Regional Studies, 50(6), 1016-1035.

Marshall, A. (1920). Principles of Economics ( $8^{\text {th }}$ ed.). London, UK: MacMillan.

Martínez-Senra, A. I., Quintás, M. A., Sartal, A., \& Vázquez, X. H. (2013). Es rentable "pensar por pensar"? Evidencia sobre innovación en España [Is it profitable 'thinking by thinking'? Evidence on innovation in Spain]. Cuadernos de Economía y Dirección de la Empresa, 16, 142-153.

Maskell, P., \& Malmberg, A. (1999). Localised learning and industrial competitiveness. Cambridge Journal of Economics, 23(2), 167-185.

Melo, P. C., Graham, D. J., \& Noland, R. B. (2009). A meta-analysis of estimates of urban agglomeration economies. Regional Science and Urban Economics, 39(3), 332-342.

Molina-Morales, F. X., García-Villaverde, P. M., \& Parra-Requena, G. (2014). Geographical and cogni- tive proximity effects on innovation performance in SMEs: a way through knowledge acquisition. International Entrepreneurship and Management Journal, 10(2), 231-251.

Montoro-Sánchez, M. A., Mora-Valentín, E. M., \& Ortiz-de-Urbina-Criado, M. (2012). Localización en parques científicos y tecnológicos y cooperación en $\mathrm{I}+\mathrm{D}+\mathrm{i}$ como factores determinantes de la innovación [Science and technology parks location and $\mathrm{R}+\mathrm{D}+\mathrm{i}$ cooperation as determinant factors of innovation]. Revista Europea de Dirección y Economía de la Empresa, 21(2), 182-190.

Morrison, A. (2008). Gatekeepers of knowledge within industrial districts: Who they are, how do they interact? Regional Studies, 42(6), 817-835.

Morrison, A., \& Rabellotti, R (2009). Knowledge and information networks in an Italian wine cluster. European Planning Studies, 17(7), 983-1006.

Murovec, N., \& Prodan, I. (2009). Absorptive capacity, its determinants, and influence on innovation output: Cross-cultural validation of the structural model. Technovation, 29(12), 859-872.

OECD/Eurostat. (2005). Oslo Manual: Guidelines for collecting and interpreting innovation data ( $3^{\text {rd }} \mathrm{ed}$.). Paris: OECD Publishing. Available from http:// www.oecd-ilibrary.org/science-and-technology/ oslo-manual_9789264013100-en

PITEC (2013). Panel de Innovación Tecnológica [Technological Innovation Panel]. Madrid: Instituto Nacional de Estadística y Fundación Española para la Ciencia y la Tecnología.

Pouder, R., \& St. John C. H. (1996). Hot spots and blind spots: Geographical clusters of firms and innovation. Academy of Management Review, 21(4), 1192-1225.

Prevezer, M. (1997). The dynamics of industrial clustering in biotechnology. Small Business Economics, 9(3), 255-271.

Rothaemel, F. T., \& Hess, A. M. (2007). Building dynamic capabilities: Innovation driven by individual-, firm-, and network-level effects. Organization Science, 18(6), 898-921.

Siegel, D. S., Westhead, P., \& Wright, M. (2003). Assessing the impact of science parks on research productivity: Exploratory firm-level evidence from the United Kingdom. International Journal of Industrial Organization, 21(9), 1357-1369. 
Sofoulli, E., \& Vonortas, N. (2007). S\&T parks and business incubator in middle-sized countries: The case of Greece. The Journal of Technology Transfer, 32(5), 525-544.

Squicciarini, M. (2008). Science parks' tenants versus out-of-park firms: Who innovates more? A Duration Model," Journal of Technology Transfer, 33(1), 45-71.

Squicciarini, M. (2009). Science parks: Seedbeds of innovation? A duration analysis of firms' patenting activity. Small Business Economics 32(2), 169-190.

Sørensen, J. B., \& Stuart, T. (2000). Aging, obsolescence and organizational innovation. Administrative Science Quarterly, 45(1), 81-112.

Stuart, T. \& Sorenson, O. (2003). The geography of opportunity: spatial heterogeneity in founding rates and the performance of biotechnology firms. Research Policy, 32(2), 229-253.

Tallman, S., Jenkins, M., Henry, N., \& Pinch, S. (2004). Knowledge, clusters and competitive advantage. The Academy of Management Review, 29(2), 258-271.

Teece, D. J., Pisano, G., \& Shuen, A. (1997). Dynamic capabilities and strategic management. Strategic Management Journal, 18(7), 509-533.

Urgal, B., Quintás, M. A. \& Arévalo-Tomé, R. (2011). Conocimiento tecnológico, capacidad de innovación y desempeño innovador: el rol moderador del ambiente interno de la empresa [Technological knowledge, innovation capability and innovative performance: the moderating role of the behavioural environment of the firm]. Cuadernos de Economía y Dirección de la Empresa, 14(1), 53-66.

Vásquez-Urriago, A. R., Barge-Gil, A., Modrego-Rico, A., \& Paraskevopoulou, E. (2014). The impact of science and technology parks on firms' product innovation: empirical evidence from Spain. Journal of Evolutionary Economics, 24(4), 835-873.

Vernon, R. (1966). International investment and international trade in the product cycle. Quarterly Journal of Economics, 80(2), 190-207.

Veugelers, R. (1997). Internal R\&D expenditures and external technology sourcing. Research Policy, 26(3), 303-315.

Westhead, P. (1997). R\&D “inputs" and "outputs" of technology-based firms located on and off science parks. RङD Management, 27(1), 45-62.
Winter, S. G. (2003). Understanding dynamic capabilities. Strategic Management Journal, 24(10), 991 995.

Yang, C. H., Motohashi, K., \& Chen, J. R. (2009). Are new technology-based firms located on science parks really more innovative, Evidence from Taiwan. Research Policy, 38(1), 77-85.

Zahra, S. A., \& George, G. (2002). Absorptive capacity: A review, reconceptualization, and extension. The Academy Management Review, 27(2), 185-203.

\section{Endnotes}

1 An estimate was carried out that included only the possible effect of a type of agglomeration economies because the simultaneous inclusion of all three types causes multicollinearity problems. 
